\title{
Perjanjian Kerjasama Internasional dalam Konstruksi Negara Kesatuan Republik Indonesia
}

\author{
Welly Angela Riry ${ }^{1}$, Efie Baadilla², Wilshen Leatemia ${ }^{3}$, Vondaal Vidya Hattu ${ }^{4}$
}

\section{1,2,3,4 Fakultas Hukum Universitas Pattimura, Ambon, Indonesia}

@ : angela.riry@gmail.com

doi : $\operatorname{xxxxxxxxxxxxx}$

Dikirim: 4/01/2021

\begin{tabular}{l}
\hline Info Artikel \\
\hline \\
Keywords: \\
International Treaties, \\
International Cooperation, \\
State Construction.
\end{tabular}

Kata Kunci:

Perjanjian Internasional, Kerjasama Internasional, Konstruksi Negar. \begin{tabular}{l} 
Direvisi: 23/02/2021 Dipublikasi: $1 / 03 / 2021$ \\
\hline Abstract
\end{tabular} Introduction: The times have demanded international cooperative
relations, including Indonesia, which is solely done to improve the welfare and prosperity of the people. International agreements are the main instrument for the implementation of international cooperative relations. Purposes of the Research: The purpose of this research is to find out and understand the position of international cooperation agreements in the construction of the Unitary State of the Republic of Indonesia.

Methods of the Research: This research is a normative study using a statutory approach with the source of legal materials used primary legal materials and secondary legal materials and tertiary legal materials with qualitative analysis with deductive and inductive methods.

Results of the Research: Every process of implementing and ratifying an international cooperation agreement must be carried out using formal statutory instruments so that the Indonesian state forms and issues a regulation in regulating all matters concerning international agreements, this proves the importance of establishing international cooperation and also shows that international cooperation agreements also become part of the construction of the Unitary State of the Republic of Indonesia.

\begin{tabular}{l}
\hline Abstrak \\
Latar Belakang: Perkembangan zaman menuntut adanya \\
hubungan kerjasama internasional termasuk Indonesia yang \\
semata-mata dilakukan untuk meningkatkan kesejahteraan dan \\
kemakmuran rakyat. Perjanjian internasional menjadi instrument \\
utama pelaksanaan hubungan kerjasama internasional. \\
Tujuan Penelitian: Mengetahui dan memahami kedudukan \\
perjanjian kerjasama internasionaldalam konstruksi Negara \\
Kesatuan Republik Indonesia. \\
Metode Penelitian: Penelitian ini merupakan penelitian normatif \\
dengan mempergunakan pendekatan perundang-undangan \\
dengan sumber bahan hukum yang digunakan adalah bahan \\
hukum primer dan bahan hukum sekunder dan bahan hukum \\
tersier dengan analisis kualitatif. \\
Hasil Penelitian: Setiap proses pelaksaan dan pengesahan suatu \\
perjanjian kerjasama internasional harus dilakukan dengan \\
menggunakan instrumen peraturan perundang-undangan yang \\
fomal sehingga negara Indonesia membentuk dan mengeluarkan \\
sebuah peraturan dalam mengatur segala hal mengenai perjanjian \\
internasional, hal ini membuktikan pentingnya menjalin \\
kerjasama internasional dan juga menunjukkan bahwa perjanjian \\
kerjasama internasional juga menjadi bagian dalam konstruksi \\
Negara Kesatuan Republik Indonesia.
\end{tabular}




\section{A. PENDAHULUAN}

Perkembangan zaman menuntut adanya kerja sama antarnegara dalam rangka perbaikan sektor kehidupan berbangsa dan bernegara baik dalam bidang politik, ekonomi, sosial, budaya, pertahanan maupun keamanan. Salah satu upaya yang dilakukan pemerintah untuk menjawab tuntutan zaman itu adalah dengan mengadakan perjanjian internasional untuk menjalin hubungan antarnegara sehingga tercipta kerja sama yang baik. Kemajuan teknologi komunikasi telah mendorong globalisasi saling ketergantungan antar negara dan antar masalah semakin erat. Akibatnya tercipta suatu dunia tanpa batas (borderless world) yang seolah-olah telah membentuk suatu global village bagi masyarakat dunia Sejalan dengan proses globalisasi tersebut, para pelaku hubungan internasional juga meluas ${ }^{1}$ tidak hanya melingkupi negara (state actors) saja, namun telah meluas pada aktor-aktor selain negara (nonstate actors) seperti organisasi internasional, LSM, perusahaan multinasional (MNCs), media, daerah, kelompok-kelompok minoritas, bahkan individu.

Perjanjian internasional sebagai satu domain hukum yang mengatur hubungan antara negara-negara nasional secara tidak langsung memberi satu sudut pandang bahwa eksistensi hukum internasional terkait erat dengan keberadaan negara-negara nasional. Lahirnya negara-negara di semua belahan bumi dikarenakan latar belakang sejarah, sosial, politik, hukum, dan budaya yang berlainan satu sama lain sehingga menciptakan tanda pengenal yang berfungsi sebagai pemersatu sebagai suatu negara namun juga sebagai pembeda antara negara satu dengan negara lainnya. ${ }^{2}$

Dalam rangka mendukung penyelenggaraan perjanjian kerjasama internasional yang lebih terarah, terpadu dan berlandaskan kepastian hukum yang lebih kuat, Pemerintah Indonesia telah memberlakukan Undang-Undang Nomor 24 Tahun 2000 tentang Perjanjian Internasional. Kedua Undang-Undang dimaksud merupakan landasan hukum yang mengikat bagi Pemerintah Pusat dan pelaku Hubungan dan Kerjasama Luar Negeri lainnya, termasuk unsur-unsur Daerah, dalam melaksanakan Hubungan dan Kerjasama Luar Negeri. Dalam rangka mendukung penyelenggaraan Hubungan dan Kerjasama Luar Negeri yang lebih terarah, terpadu dan berlandaskan kepastian hukum yang lebih kuat, Pemerintah Indonesia telah memberlakukan Undang-Undang Nomor 37 Tahun 1999 tentang Hubungan Luar Negeri dan Undang-Undang Nomor 24 Tahun 2000 tentang Perjanjian Internasional. Kedua Undang-Undang dimaksud merupakan landasan hukum yang mengikat bagi Pemerintah Pusat dan pelaku Hubungan dan Kerjasama Luar Negeri lainnya, termasuk unsur-unsur Daerah, dalam melaksanakan Hubungan dan Kerjasama Internasional sebagai bagian dari konstruksi Negara Kesatuan Republik Indonesia.

\section{B. METODE PENELITIAN}

Penelitian ini merupakan penelitian hukum hukum normatif. ${ }^{3}$ Penelitian hukum ini dilakukan dengan cara kepustakaan atau disebut juga "Legal Research". 4 Metode pendekatannya yaitu pendekatan perundang-undangan, pendekatan konseptual, pendekatan analitis ${ }^{5}$. Jenis dan sumber bahan hukum yaitu bahan hukum primer, merupakan bahan

1 Malcolm N Shaw, International Law (Cambridge: Cambridge University Press, 2003).

2 Firdaus, "Kedudukan Hukum Internasional Dalam Sistem Perundang-Undangan Nasional Indonesia," FIAT JUSTISIA:Jurnal Ilmu Hukum 8, no. 1 (2014): 36-52, https:/ / doi.org/10.25041/fiatjustisia.v8no1.285, h. 37.

3 Syahruddin Nawi, Penelitian Hukum Normatif Versus Penelitian Hukum Empiris (Makassar: Umitoha Ukhuwah Grafika, 2018), h. 7.

4 Soerjono Soekanto and Sri Mamudji, Penelitian Hukum Normatif, Suatu Tinjauan Singkat, Jakarta: Raja Grafindo Persada (Jakarta: Rajawali Pers, 2015), h. 23.

5 Irwansyah, Penelitian Hukum (Pilihan Metode \& Praktik Penulisan Artikel) (Yogyakarta: Mirra Buana Media, 2020), h. 133. 
hukum yang bersumber dari peraturan perundang-undangan, yakni Undang-Undang Dasar Negara Republik Indonesia tahun 1945, Vienna Convention On The Law of Treaties 1969, dan Undang-Undang Nomor 24 Tahun 2000 tentang Perjanjian Internasional. Bahan hukum sekunder yang yaitu berupa buku, jurnal, artikel, naskah ilmiah di bidang hukum. Selanjutnya, bahan hukum tersier untuk melengkapi bahan hokum primer dan sekunder berupa kamus umum, kamus hukum. Analisis bahan hukum yang digunakan yaitu analisis kualitatif karena penelitian ini merupakan penelitian hukum kepustakaan yang merupakan bahan-bahan hukum yaitu bahan hukum primer, sekunder maupun tersier. ${ }^{6}$

\section{HASIL DAN PEMBAHASAN}

Sesuai dengan hukum perjanjian internasional dalam Pasal 6 Konvensi Wina 1969 maka setiap negara mempunyai kemampuan untuk membuat sebuah perjanjian internasional. Perjanjian internasional dalam hukum internasional diatur dalam Konvensi Wina 1969 Tentang Perjanjian Internasional. Pengertian perjanjian internasional sendiri terdapat dalam Pasal 2 ayat (1) huruf a Konvensi Wina 1969 yang mengatur bahwa: "An international agreement concludes between states in written form and governed by international law, whether embodied in a single instrument or in two or more instruments and whatever its particular designation" 7 . Pasal tersebut secara garis besar menyebutkan bahwa Perjanjian Internasional adalah perjanjian dalam bentuk dan nama tertentu yang diatur dalam hukum internasional yang dibuat secara tertulis serta menimbulkan hak dan kewajiban dibidang hukum publik. Ketika negara mempunyai kemampuan untuk membuat perjanjian internasional timbul pertanyaan siapakah atau badan manakah yang mempunyai kekuasaan atau wewenang untuk membentuk perjanjian internasional (treaty making power) pada dasarnya merupakan intern suatu negera. Pada dasarnya organ yang berwenang mengatur perjanjian internasional diatur dalam Konstitusi (Undang-Undang Dasar) negara tersebut.

Kekuasaan/wewenang membentuk perjanjian internasional di Indonesia didasarkan pada Pasal 11 Undang-Undang Dasar 1945 ayat (1), (2), dan (3) yang menegaskan bahwa :

(1) Presiden dengan persetujuan Dewan Perwakilan Rakyat menyatakan perang, membuat perdamaian dan perjanjian dengan negara lain;

(2) Presiden dalam membuat perjanjian internasional lainnya yang menimbulkan akibat yang luas dan mendasar bagi kehidupan rakyat yang terkait dengan beban keuangan negara, dan/atau mengharuskan perubahan atau pembentukan undangundang harus dengan persetujuan Dewan Perwakilan Rakyat;

(3) Ketentuan lebih lanjut tentang perjanjian internasional diatur dengan undangundang".

Ketentuan Pasal 11 Undang-Undang Dasar 1945 (UUD 1945) merupakan dasar hukum bagi Indonesia untuk membentuk atau mengikatkan diri pada perjanjian internasional; baik yang dilakukan dengan satu negara (bilateral) maupun yang dilakukan Indonesia dengan banyak negara (multilateral). Dalam hal ini kekuasaan untuk membentuk perjanjian internasional merupakan perwujudan kekuasaan Presiden dalam hubungan internasional; selain mengakngkat duta dan konsul serta menerima duta negara lain berdasarkan pasal 13 Undang-Undang Dasar 1945.

Sesuai dengan ketentuan Pasal 11 UUD 1945, maka kekuasaan Presiden untuk membentuk perjanjian internasional merupakan pelaksanaan kekuasaan presiden sebagai

6 Nurul Qamar et al., Metode Penelitian Hukum (Legal Research Methods) (Makassar: Social Political Genius, 2017), h. 53.

7 Anthony Aust, Handbook of International Law (Cambridge: Cambridge University Press, 2012), https://doi.org/10.1017/CBO9780511841460, h. 50. 
Kepala Negara. Selain memegang kekuasaan sebagai Kepala Negara; Presiden menurut UUD 1945 juga memegang kekuasaan di bidang Eksekutif (sebagai kepala pemerintahan) dan kekuasaan dalam bidang Legislatif.

Kedudukan Presiden sebagai Kepala Negara tidak dapat dipisahkan dari kedudukannya sebagai Kepala Pemerintahan (pimpinan Eksekutif) dalam melaksanakan kekuasaannya membentuk perjanjian internasional. Sebab dilihat dari segi hukum perjanjian internasional baik Kepala Negara maupun Kepala Pemerintahan diakui sebagai organ yang mewakili Negara untuk membentuk perjanjian internasional. 8 Presiden memegang kekuasaan sebagai kepala negara maupun sebagai kepala pemerintahan, maka pembentukan perjanjian internasional oleh presiden, hanya dapat dibedakan berdasarkan jenis perjanjian yang ditandatangani. Terhadap perjanjian yang dilakukan antar kepala negara, dilakukan oleh presiden dalam kedudukannya sebagai kepala negara; sedangkan terhadap perjanjian antar kepala pemerintahan, ditandatangani presiden sebagai kepala pemerintahan. Kekuasaan presiden untuk membentuk perjanjian dalam kedudukannya sebagai kepala pemerintahan, didasarkan pada Pasal 4 ayat (1) UUD 1945 yang menegaskan bahwa "Presiden Republik Indonesia memegang kekuasaan pemerintahan menurut Undang-Undang Dasar".

Oleh karena UUD 1945 mengatur hal-hal yang pokok, maka ketentuan Pasal 4 ayat (1) di atas memberikan wewenang kepada presiden yang luas dan tidak terperinci, ${ }^{9}$ dalam hal ini presiden sebagai pemegang kekuasaan pemerintah menyelenggarakan urusan pemerintahan yang meliputi kehidupan negara dan masyarakatnya; baik mengenai hubungan antara sesama warga negaranya maupun hubungan antara negara dengan negara asing. ${ }^{10}$ Hubungan antar negara (Indonesia) dengan negara asing, diwujudkan terutama dalam bentuk perjanjian internasional baik bilateral maupun multilateral.

Presiden dalam membentuk perjanjian internasional sebagai kepala negara maupun kepala pemerintahan; pelaksanaannya dapat dilakukan oleh pejabat lain yang kedudukannya baik dilihat dari hukum nasional maupun hukum internasional, diakui sebagai berwenang mengadakan perundingan dan penandatanganan suatu perjanjian / persetujuan internasional. ${ }^{11}$ Baik menurut hukum internasional maupun hukum nasional Indonesia, pejabat yang berwenang mengadakan perjanjian internasional selain kepala negara dan kepala pemerintahan adalah Menteri Luar Negeri.

Menurut hukum internasional, menteri luar negeri dipandang sebagai petugas negara yang berwenang mengadakan hubungan-hubungan secara langsung atau lewat wakil-wakil diplomatik di luar negeri dengan negara-negara (pemerintah) lain untuk mengadakan perundingan, perjanjian dan sebagainya. ${ }^{12}$ Dilain pihak menurut hukum nasional Indonesia, kedudukan Menteri Luar Negeri adalah sebagai pembantu presiden dalam menjalankan pemerintahan di bidang hubungan luar negeri (hubungan internasional) dengan negara lain. Kedudukan menteri luar negeri sebagai pembantu presiden adalah sebagai pimpinan Departemen Luar Negeri; yang merupakan bagian pemerintahan negara dalam menyelenggarakan sebagian tugas umum pemerintahan dan pembangunan di bidang politik dan hubungan luar negeri, dalam hal ini Menteri Luar Negeri melaksanakan/menjalankan

8 Danel Aditia Situngkir, "Perjanjian Internasional Dan Dampaknya Bagi Hukum Nasional," Kertha Wijaksana 13, no. 1 (2019), https:/ / doi.org/10.22225/kw.13.1.921.19-25, h. 22.

9 Moh. Kusnadi and Harmaily Ibrahim, Pengantar Hukum Tata Negara Indonesia (Jakarta: Budi Chaniago, 1980), h. 93.

10 M. Solly Lubis, Asas-Asas Hukum Tata Negara (Bandung: Alumni, 1982), h. 102.

11 B Manan, “Kekuasaan Presiden Untuk Membuat, Memasuki Dan Mengerahkan Perjanjian/Perstujuan Internasional," Majalah Padjajaran 3, no. 4 (1986), h. 15.

12 Ali Sastroamidjojo, Pengantar Hukum Internasional (Jakarta: Bhratara, 1971), 164. 
fungsi eksekutif (Pemerintahan); dalam mengimplementasikan politik luar negeri dan mengelola hubungan internasional.

Dalam Perjanjian kerjasama internasional selain laksanakan oleh kepala negara atau pemerintah pusat namun dapat pula dilakukan antar daerah dengan pihak luar negeri dalam rangka menunjang peningkatan penyelenggaraan pemerintahan dan pelaksanaan pembangunan dalam Pasal 1 sub b PERMENDAGRI, Nomor 1 Tahun 1992; berkaitan dengan pelaksanaan kekuasaan Pemerintahan oleh Presiden. Alasannya adalah:

1) Pengertian pemerintahan dalam arti luas mencakup segala urusan yang dilakukan oleh negara dalam menyelenggarakan kesejahteraan rakyatnyaa dan kepentingan negara sendiri. ${ }^{13}$ Kerjasama antar daerah sebagai bagian kerjasama Jajaran Departemen Dalam Negeri dengan pihak luar negeri, diselenggarakan sebagai pelengkap dalam pelaksanaan pembangunan nasional dan daerah. Tujuannya adalah :

a) Menunjang pelaksanaan program pembangunan nasional dan daerah;

b) Membantu meningkatkan taraf hidup, kesejahteraan dan kecerdasan masyarakat;

c) Membantu meningkatkan kemampuan Pemerintah Daerah dalam melaksanakan tugas-tugas pemerintahan dan pembangunan.

2) Adanya pelimpahan wewenang Pemerintah Pusat kepada Pemerintah Daerah dalam Negara Indonesia merupakan gagasan yang telah diterima dan disepakati sejak negara Indonesia memiliki UUD 1945. Pembagian wilayah Indonesia menjadi daerah besar dan kecil yang mempunyai bentuk dan susunan pemerintahan berdasarkan Pasal 18 UUD 1945; menunjukkan bahwa dalam penyelenggaraan pemerintahan di Indonesia ada pelimpahan wewenang dari Pemerintah Pusat di atas. Sebab untuk mengurus penyelenggaraan pemerintahan negara sampai kepada seluruh daerah negara, maka dibentuk Pemerintah Daerah. Pemerintahan Daerah ini sebenarnya menyelenggarakan pemerintahan secara langsung berhubungan dengan masyarakat. ${ }^{14}$ Apabila hal ini dikaitkan dengan tujuan kerjasama antar daerah di atas maka pelimpahan wewenang Pemerintah Pusat kepada Pemerintah Daerah (daerah) untuk melaksanakan kerjasama menjadi sangat penting.

3) Kerjasama antar daerah sebagai bagian kerjasama luar negeri dalam pelaksanaannya menjadi tanggung jawab Menteri Luar Negeri secara umum. Kedudukan Menteri Luar Negeri adalah sebagai pembantu Presiden sesuai Pasal 17 UUD 1945. Di lain pihak kedudukan Pemerintah Daerah (daerah) dalam kerjasama antar daerah adalah sebagai pelaksana teknis yang bertanggungjawab kepada Menteri Luar Negeri. Sebagai pelaksana teknis, Pemerintah Daerah dalam pelaksanaan kerjasama antar daerah bertindak sebagai mandataris (penerima mandat) dari Pemerintah Pusat (Menteri Luar Negeri). ${ }^{15}$

Pelaksanaan kekuasaan Presiden untuk membuat perjanjian internasional, dilakukan dengan persetujuan Dewan Perwakilan Rakyat (DPR). Keikutsertaan DPR berupa persetujuan kepada Presiden untuk membuat perjanjian internasional adalah dalam rangka "checks and balances". DPR melakukan "checking and balancing" terhadap kekuasaan Presiden dalam membuat perjanjian internasional; artinya kekuasaan itu tetap berada di tangan Presiden. ${ }^{16}$

13 Kusnadi and Ibrahim, Pengantar Hukum Tata Negara Indonesia. Op. Cit. h. 85.

14 Kusnadi and Ibrahim, Ibid. h. 123.

15 Welly Angela Riry, "Kewenangan Pemerintah Daerah Dalam Melakukan Perjanjian Internasional" (Skripsi: Universitas Pattimura, 2013), h. 51.

16 Manan, "Kekuasaan Presiden Untuk Membuat, Memasuki Dan Mengerahkan Perjanjian/Perstujuan Internasional." Op. Cit. h. 15. 
Sebaliknya dengan melakukan "checking and balancing", tidak berarti DPR mempunyai kekuasaan yang berdiri sendiri atas masalah hubungan internasional. Sebab kekuasaan "check and balances" dari DPR tergantung dari kekuasaan Presiden untuk membuat perjanjian internasional, baik bilateral maupun multilateral. Apabila Presiden tidak membuat perjanjian Internasional maka kekuasaan DPR tersebut tidak dilaksanakan. Keikutsertaan DPR berupa persetujuan kepada Presiden membuat perjanjian internasional berdasarkan Pasal 11 UUD 1945, adalah dalam rangka mencegah kemungkinan Presiden menyalahgunakan kekuasaan tersebut.Karena belum adanya peraturan perundang-undangan sebagai penjabaran Pasal 11 UUD 1945; maka praktek kenegaraan yang berlaku di Indonesia mempunyai kedudukan penting.

Berdasarkan praktek ketatanegaraan Indonesia berkaitan dengan pembentukan perjanjian internasional oleh Presiden; maka tidak semua perjanjian harus mendapat persetujuan DPR. Sesuai dengan Surat Presiden kepada Ketua DPR Nomor 2826/HK/1960 tanggal 22 Agustus 1960 tentang Pembuatan Perjanjian-Perjanjian dengan Negara Lain; menyatakan :

“Menurut pendapat Pemerintah perkataan "perjanjian" didalam Pasal 11 ini tidak mengandung arti segala perjanjian dengan negara asing, tetapi hanya perjanjianperjanjian terpenting saja, yaitu yang mengandung soal-soal politik dan yang lazimnya dikehendaki berbentuk traktat (treaty)".

Dengan demikian praktek pembentukan perjanjian internasional oleh Presiden dibedakan antara (a) perjanjian dalam bentuk traktat (treaty) yang membutuhkan persetujuan DPR sebelum disahkan Presiden; dan (b) perjanjian dalam bentuk pesetujuan (agreement) yang disahkan Presiden tanpa persetujuan terlebih dahulu dari DPR. Dalam hal ini menurut Surat Presiden Nomor 2826/HK/1960 di atas bahwa:

“... Pemerintah akan menyampaikan kepada Dewan Perwakilan Rakyat untuk memperoleh persetujuan DPR, hanya perjanjian-perjanjian yang terpenting saja (treaties); sedangkan perjanjian-perjanjian lain (agreement) akan disampaikan kepada DPR hanya untuk diketahui".

Dalam hal ini perjanjian-perjanjian yang harus mendapatkan persetujuan DPR sebelum disahkan oleh Presiden adalah perjanjian yang mengandung materi : (a) soal-soal politik atau soal-soal yang dapat mempengaruhi haluan politik luar negeri Negara; (b) ikatan-ikatan sedemikian rupa sifatnya sehingga mempengaruhi politik luar negeri Negara; (c) soal-soal yang menurut UUD atau menurut sistem perundang-undangan harus diatur dengan UndangUndang seperti soal kewarganegaraan dan kehakiman.

Sebagai alasan mengapa tidak semua perjanjian harus memperoleh persetujuan DPR adalah : (a) apabila semua perjanjian internasional memerlukan persetujuan DPR sebelum disahkan Presiden, maka Pemerintah tidak akan mempunyai keleluasaan bergerak untuk menjalankan hubungan internasional dengan sewajarnya; (b) prosedur konstitusional yang lancer akan mendorong tindakan-tindakan cepat dari Pemerintah terhadap perkembangan hubungan internasional yang semakin intensif; dan (c) adanya beranekaragam materi perjanjian internasional bak mengenai masalah-masalah penting dan besar seta ada yang mengenai hal-hal yang sifatnya teknis dan kecil-kecil saja. Namun, Surat Presiden Republik Indonesia No.2826/HK/1960 yang selama ini digunakan sebagai pedomon untuk membuat dan mengesahkan perjanjian internasional sudah tidak sesuai lagi dengan perkembangan saat ini. Oleh sebab itu pembuatan dan pengesahan suatu perjanjian internasional harus dilakukan dengan dasar-dasar yang jelas dan kuat, dengan menggunakan instrumen peraturan perundang-undangan yang jelas pula, sehingga negara Indonesia membentuk dan mengeluarkan sebuah peraturan dalam mengatur segala hal mengenai perjanjian 
internasional melalui Undang-Undang Republik Indonesia Nomor 24 Tahun 2000 tentang Perjanjian Internasional.

Terdapat dua alasan yang memperlihatkan bahwa Perjanjian kerjasama antara negara menjadi bagian dari konstruksi Negara Kesatuan Republik Indonesia yang ditunjukkan di dalam sistem perundang- undangan Indonesia yaitu Undang-undang Nomor 24 Tahun 2000 Tentang Perjanjian Internasional. Alasan pertama yaitu dasar menimbang huruf a secara garis besar menetapkan aturan untuk membuat perjanjian kerjasama internasional dalam rangka mencapai tujuan negara yang sesuai dengan Pembukaan UUD 1945, yaitu melindungi segenap bangsa Indonesia dan seluruh tumpah darah Indonesia, memajukan kesejahteraan umum, mencerdaskan kehidupan bangsa serta ikut melaksanakan ketertiban dunia yang berdasarkan kemerdekaan, perdamaian abadi, dan keadilan social yang menunjukkan bahwa Negara Indonesia juga merupakan bagian dari masyarakat internasional. ${ }^{17}$ Alasan kedua, yaitu di dalam Pasal 9 ayat (1) Undang-Undang Nomor 24 Tahun 2000 menyatakakan Pengesahan perjanjian internasional oleh Pemerintah RI dilakukan sepanjang dipersyaratkan oleh perjanjian internasional tersebut dan ayat (2) Pengesahan perjanjian internasional sebagaimana dimaksud dalam ayat (1) dilakukan dengan undang-undang atau Keputusan Presiden.

Selain kedua alasan di atas, di dalam Pasal 10 Undang - undang Nomor 24 Tahun 2000 menentukan materi muatan Perjanjian Internasional yang harus diatur dengan undangundang antara lain: a. masalah politik, perdamaian, pertahanan, dan keamanan negara; $b$. perubahan wilayah atau penetapan batas wilayah negara Republik Indonesia; c. kedaulatan atau hak berdaulat negara; d. hak asasi manusia dan lingkungan hidup; e. pembentukan kaidah hukum baru; dan f. pinjaman dan/atau hibah luar negeri. Berdasarkan hal di atas maka secara hukum kedudukan perjanjian kerjasama internasional ada dalam sistem perundangundangan Indonesia yaitu dalam Undang-Undang dan Keputusan Presiden.

\section{P E N U T P}

Dari uraian hasil dan pembahasan di atas terlihat Undang-Undang Dasar 1945 Pasal 11 menjadi dasar hukum dan menjadikan perjanjian kerjasama internasional dan bagian dari konstruksi Negara Kesatuan Republik Indonesia. Pemerintah memiliki kewenangan untuk membuat dan melakukan perjanjian kerjasama internasional, maka pemerintah membentuk Undang-Undang terkait dengan perjanjian internasional yang menjadi sumber hukum bagi negara Indonesia dalam melakukan perjanjian kerjasama internasional. Undang-undang Nomor 24 Tahun 2000 Tentang Perjanjian Internasional sampai saat ini yang menjadi pedoman bagi Pemerintah Indonesia untuk melaksanakan perjanjian kerjasama antara internasional dan untuk memperjelas keberadaan Perjanjian kerjasama internasional dalam konstruksi Negara Kesatuan Republik Indonesia.

\section{REFERENSI}

Aust, Anthony. Handbook of International Law. Cambridge: Cambridge University Press, 2012. https:// doi.org/10.1017/CBO9780511841460.

Firdaus. "Kedudukan Hukum Internasional Dalam Sistem Perundang-Undangan Nasional Indonesia." FIAT JUSTISIA:Jurnal Ilmu Hukum 8, no. 1 (2014): 36-52. https:// doi.org/10.25041/fiatjustisia.v8no1.285.

17 Firdaus, "Kedudukan Hukum Internasional Dalam Sistem Perundang-Undangan Nasional Indonesia." h. 48. 
Irwansyah. Penelitian Hukum (Pilihan Metode E Praktik Penulisan Artikel). Yogyakarta: Mirra Buana Media, 2020.

Kusnadi, Moh., and Harmaily Ibrahim. Pengantar Hukum Tata Negara Indonesia. Jakarta: Budi Chaniago, 1980.

Lubis, M. Solly. Asas-Asas Hukum Tata Negara. Bandung: Alumni, 1982.

Manan, B. "Kekuasaan Presiden Untuk Membuat, Memasuki Dan Mengerahkan Perjanjian/Perstujuan Internasional." Majalah Padjajaran 3, no. 4 (1986).

Nawi, Syahruddin. Penelitian Hukum Normatif Versus Penelitian Hukum Empiris. Makassar: Umitoha Ukhuwah Grafika, 2018.

Qamar, Nurul, Muhammad Syarif, Dachran S Busthami, M Kamal Hidjaz, Aan Aswari, Hardianto Djanggih, and Farah Syah Rezah. Metode Penelitian Hukum (Legal Research Methods). Makassar: Social Political Genius, 2017.

Riry, Welly Angela. "Kewenangan Pemerintah Daerah Dalam Melakukan Perjanjian Internasional." Skripsi: Universitas Pattimura, 2013.

Sastroamidjojo, Ali. Pengantar Hukum Internasional. Jakarta: Bhratara, 1971.

Shaw, Malcolm N. International Law. Cambridge: Cambridge University Press, 2003.

Situngkir, Danel Aditia. "Perjanjian Internasional Dan Dampaknya Bagi Hukum Nasional." Kertha Wijaksana 13, no. 1 (2019). https:/ / doi.org/10.22225/kw.13.1.921.19-25.

Soekanto, Soerjono, and Sri Mamudji. Penelitian Hukum Normatif, Suatu Tinjauan Singkat. Jakarta : Raja Grafindo Persada. Jakarta: Rajawali Pers, 2015. 